\title{
HIV Apheresis Tags (HIVAT) Aided Elimination of Viremia
}

\author{
Marek Malecki, M.D., Ph.D. and Bianka Saetre, M.D. \\ Phoenix Biomolecular Engineering Foundation, San Francisco, CA, USA
}

\begin{abstract}
Introduction-HIV viremia is the essential element for progression of an initial HIV infection into AIDS and death. The currently approved management relies primarily on chemotherapy repressing the HIV replication in the infected CD4+ cells, although with severe systemic adverse effects. The problem is that it does not physically eliminate viruses, which then not only keep infecting healthy cells of these patients, but also promote infections of other people.
\end{abstract}

Specific aim-An overall objective of our work is biomolecular engineering of virus apheresis tags (VAT) that eliminate viremias without adverse effects. The specific aim of this project was biomolecular engineering of Human Immunodeficiency Virus Apheresis Tags (HIVAT): CD4-Au$\mathrm{Fe}_{3} \mathrm{O}_{4}, \mathrm{CD} 4-\mathrm{SiO}_{2}-\mathrm{Fe}_{3} \mathrm{O}_{4}$, anti-gp120-Au-Fe $\mathrm{O}_{4}$, and anti-gp120- $\mathrm{SiO}_{2}-\mathrm{Fe}_{3} \mathrm{O}_{4}$.

Healthy Donors and Patients-Per the Institutional Review Board's approval and in compliance with Declaration of Helsinki, healthy donors and patients were presented with Patient Bill of Rights and provided Patient Informed Consent, while all the procedures were pursued by the licensed physicians.

Materials and Methods-CD4, gp120, gp41, gp160, anti-gp120, p24 were transgenomically expressed. Superparamagnetic core-shell particles (SPM-CSP) were synthesized. SPM-CSP were used as the nucleation centers for assembling the expressed molecules upon them to create virus apheresis tags (VAT). VAT were injected into the blood or lymph acquired from the HIV+ and $\mathrm{HBV}+$ patients followed by apheresis at $0.47-9.4 \mathrm{~T}$. VAT efficacy in eliminating viremia was determined through immunoblots, NMR and q-RT-PCR.

Results-Treatment of blood or lymph of the HIV+ patients' with VAT followed by virus apheresis resulted in rapid elimination of the HIV viremia. Efficacy of apheresis was contingent upon the gravity of viremia versus doses and regimens of VAT. Importantly, administration of VAT also effectively improved levels of non-infected CD4+ lymphocytes.

Discussion / Conclusions-Herein, we present the proof of concept for a new, effective treatment with virus apheresis tags (VAT), specifically Human Immunodeficiency Virus Apheresis Tags (HIVAT), of the HIV+ patients' blood and lymph, which is eliminating the HIV viremia.

It can be easily adapted as treatments of viremias perpetrated by other deadly viruses, which we vigorously pursue.

Corresponding Author Marek Malecki, M.D., Ph.D., Phoenix Biomolecular Engineering Foundation, POB 191111, San Francisco, CA 94119, USA; mm@ @bmef.org or marekmaleckimdphd@pbmef.org; phone: 4157134370; skype: mm-pbmef. 


\section{Keywords}

Human Immunodeficiency Virus (HIV); viremia; Acquired Immunodeficiency Syndrome (AIDS); superparamagnetic particle (SPM); Cluster of Differentiation 4 (CD4); glycoprotein 160 (gp160); glycoprotein 120 (gp120); glycoprotein 41 (gp41); anti-gp160; anti-gp120; anti-gp41; CD4+ lymphocyte; apheresis; virus apheresis tag (VAT); Human Immunodeficiency Virus Apheresis Tag (HIVAT)

\section{INTRODUCTION}

According to the World Health Organization, approximately 36.7 million people suffered from AIDS in 2016 and approximately 1 million of them died that year, while almost 1.8 million became newly infected. [1-3]

Currently, there are no prophylactic HIV vaccines approved and / or recommended neither by WHO, nor by FDA in the United States, although the vigorous research continues. [3-8]

HIV viremia is the essential element of progression of an initial HIV infection into AIDS and death. Within 6 weeks from the moment of infection, the HIV viremia rapidly increases up to $10^{\wedge} 8$ copies of RNA per milliliter of plasma. At the same time, the population of CD4 cell $\mathrm{T}$ lymphocytes, the primary target for HIV, declines down to 500 cells per microliter. Presence in blood of HIV p24 shortly precedes other HIV proteins gp160, gp120, gp41. That is followed by raising $\operatorname{IgM}$ subsequently switched to $\operatorname{IgG}$. Thereafter, there is a short period of time of the viremia decrease and CD4 population increase. Nevertheless, the HIV viremia persists at all stages. And so do HIV cell reservoirs. However, since 8-10 weeks until death, the HIV viremia is constantly increasing up to $10^{\wedge} 8$ copies of RNA per milliliter of plasma and the healthy CD4+ populations are constantly apoptotically declining. This is associated with the complete annihilation of the CD4 cell population, while patients suffer advancing stages of AIDS and death. [9-35]

Currently, there are no therapeutic HIV vaccines and / or immunotherapies approved and / or recommended neither by WHO, nor by FDA, despite the vigorous research. Although, attempts to develop therapeutic vaccines or therapeutics relying upon soluble CD4 and neutralizing anti-gp120 antibodies, as well as on genetic engineering of CD4, CXCR5, CXCR4 are vigorously pursued. [36-48]

At the present time, therapy of the HIV+ patients relies upon administration of drugs repressing HIV propagation mechanisms: entry inhibitors (e.g., enfuvirtide or maraviroc), reverse transcriptase inhibitors (e.g., zidovudine or tenofovir), integrase inhibitors (e.g., elvitegravir) or protease inhibitors (e.g., darunavir). Although, all currently approved chemotherapies cause very serious adverse effects. Moreover, the choice of the therapeutic cocktails has different impact upon the HIV-infected cells. [3, 49-52]

The main problems with aforementioned therapies are, that they do not directly eliminate the HIV viremia, i.e., they do not physically remove the virus from the patients' bodies, and they do not remove the HIV infected CD4+ cells. Therefore, HIV keep replicating and infecting healthy CD4+ cells, so that the HIV+ patients not only keep suffering progression 
of the disease due to disabling of the immune system, but also potentially continue infecting others through blood and lymph e.g., by shared needles, as well as by all physiological secretions e.g., during sex. [1-3]

\section{SPECIFIC AIM}

An overall objective of our work is biomolecular engineering of virus apheresis tags (VAT) that facilitate elimination of viremia without adverse effects. The specific aim of this project was biomolecular engineering of Human Immunodeficiency Virus Apheresis Tags (HIVAT): $\mathrm{CD} 4-\mathrm{Au}-\mathrm{Fe}_{3} \mathrm{O}_{4}, \mathrm{CD} 4-\mathrm{SiO}_{2}-\mathrm{Fe}_{3} \mathrm{O}_{4}$, anti-gp120-Au- $\mathrm{Fe}_{3} \mathrm{O}_{4}$, and anti-gp120-SiO2- $\mathrm{Fe}_{3} \mathrm{O}_{4}$.

\section{HEALTHY DONORS AND PATIENTS}

Per the Institutional Review Board approval and in compliance with the Declaration of Helsinki, all healthy donors and patients were presented with the Patient Bill of Rights and provided Patient Informed Consent with their identities entirely concealed, while all the procedures involving them were pursued by the licensed physicians.

Six healthy volunteers (three women, three men) had no past or present diseases in their medical records, so they were not taking any medications. Results of their routine laboratory tests of blood, with emphasis on ESR and immunoglobulin profiles, and of urine, with emphasis on potential presence of cells and proteins, and basic tests for assuring absence of viral infections, were within laboratory norms.

Three oncology patients (all males) were diagnosed with Kaposi sarcomas. [53-54] Their blood routine laboratory tests revealed low counts of CD4+ lymphocytes, but increased ESR. These results prompted us to test for Human Immunodeficiency Virus (HIV), Herpes Simplex Virus (HSV), Cyto-megalo-virus (CMV), Human Papilloma Virus (HPV). The HIV tests came out positive, but the HSV, HPV, and CMV tests came out negative. These patients had not received any therapy prior to admission.

Five oncology patients (three women, two men) were diagnosed with Multiple myelomas. Their blood routine laboratory tests revealed high ESR. These results prompted us to test for protein profiles, which revealed high immunoglobulin. Their urine routine laboratory tests revealed protein presence, identified as Bence-Jones protein. These patients were treated by aspiration of pleural and peritoneal effusion as the first therapeutic steps, but had not received prior chemotherapy.

Three oncology patients were diagnosed with Hepatocellular carcinoma and admitted for surgical treatment with intrahepatic artery infusion. Chronic Hepatitis B was in their medical histories. Four oncology patients were diagnosed with Acute or Chronic Hepatitis B, while admitted for other surgical therapy of non-liver cancers. 


\section{MATERIALS \& METHODS}

\section{Blood, lymph, plasma, effusion, virus}

Acquisition, processing, storage, and culture of blood, erythrocyte-free blood, peritoneal or pleural effusions, lymph, and plasma were pursued according to the original, detailed protocols published earlier and only briefly outlined here. [8-27, 53-68]

Blood was drawn according to the standard clinical procedure by venipuncture into citric acid / dextran receiving buffer. It was stored at $4 \mathrm{deg}$. $\mathrm{C}$ until further processing. For virus binding assays, the blood was depleted of fibrinogen and calcium (later re-adjusted to physiological levels). Erythrocyte-free blood was prepared by magnetophoresis aided by antibodies conjugated with magnetic beads. Plasma was prepared by simple sedimentation and collecting supernatant or alternatively sampled during plasmapheresis. T cell fractions were prepared by activated sheep erythrocyte resetting. B cells were removed by complement receptor activated lysis. Desired cell fractions were enriched by FACS after labeling with fluorescent antibodies or by MACS after labeling with superparamagnetic antibodies. Plasma and B cells were isolated from erythrocyte-free blood by MACS after labeling with anti-CD19 and anti-CD20 magnetic antibodies.

Lymph was acquired according to the standard clinical procedure during surgeries on the open abdomens. The viruses and cells from lymph were prepared according to the protocols for erythrocyte-free blood.

All the samples were processed on various ways depending on the research plans: secured for long term storing or processed immediately upon being drawn.

For storing, the samples were prepared primarily by cryo-biobanking. The samples were equilibrated with $10 \%$ DMSO in the patients' serum at $4 \mathrm{deg} \mathrm{C}$. They were frozen according to the gradual lowering temperature down to $-35 \operatorname{deg} \mathrm{C},-70 \operatorname{deg} \mathrm{C},-196 \operatorname{deg} \mathrm{C}$ per $24 \mathrm{~h}$ on each step (Cryo-immobilization apparatus was constructed and protocols for it developed thanks to the NSF Grant to MM). These samples were stored indefinitely without compromised quality. When needed, these samples were thawed according to the reverse-tofreezing protocol for processing (The cryo-apparatus aa). Alternatively, HIV was collected on filter papers for genomic studies. [23-25] Alternatively, total RNA was prepared and either stored as such or converted into cDNA for storing and / or shipping. [60-66]

HIV was propagated from the aforementioned aspiration as specifically described in the original protocols. [56-60]

For immediate processing, the HIV+ patients' viremia samples in blood, lymph, effusion, or plasma were tested by reverse transcription and polymerase chain amplification of the sequences nested by the primers designed upon the published HIV-1 sequences in [GenBank] from the samples generated by isolation of total RNA. [SEQ ID NO: 6-8] [2326, 58-62, 64-66] The healthy donors' blood, lymph, and plasma served as the controls and processed in parallel to those of the HIV+ patients. 
The samples acquired from the HIV+ patients, whose HIV counts were adjusted to the concentrations needed for particular tests, were spiked with VAT, with doses and regimens indicated in the Results. The infected samples in vials were incubated at the desired time at 37 deg. $\mathrm{C}, 5 \% \mathrm{CO} 2$, while on the gyroscopic tables.

Depending on the plans for further tests, lysis of the cells was pursued in two buffers: NP40 and RIPA, as outlined in the forthcoming section. In NP40, they were prepared for immunoprecipitation (IP). In RIPA, they were prepared for immunoblotting (IL).

HIV were aspirated from the peritoneal or pleural effusions of the HIV+ oncology patients, who were diagnosed with Kaposi sarcoma. Of these sterile effusions, 100 microliter sample, which was containing the HIV copy number determined by RT-PCR, was injected into in the H9 culture (ATCC) and propagated strictly according to the detailed published protocols. [58-62]

\section{Human CD4 - Human Immunodeficiency Virus Attachment and Entry Receptor (HIVAER)}

Human CD4 was manufactured on different ways: cell lysis - immunoprecipitation immunoblotting, magnetic activated molecular sorting - affinity chromatography, and genomic isolation - amplification - recombination. T lymphocytes from healthy volunteers were initially selected by sheep erythrocyte rosetting precipitation followed by B cell complement lysis. Later, these fractions were enriched by CD4+ selection with our anti-CD4 superparamagnetic antibodies on MACS or our anti-CD4 fluorescent antibodies by FACS. [8, 18-20, 63-66, 75] [SEQ ID NO: 1-5]

For immunoprecipitation, the enriched fractions of the CD4+ cells were lysed with NP40. The soup was mixed with our anti-CD4, superparamagnetic, genomically engineered antibodies, incubated for $1 \mathrm{~h}$ at $4 \mathrm{deg}$. $\mathrm{C}$, and inserted into magnetic field at room temperature for 15 minutes. Diamagnetic content was rinsed off, while in the field. The fraction retained by our superparamagnetic anti-CD4 antibodies was released after the magnetic field ceased. Aliquots of this fraction were electrophoresed on PAGE and transferred onto the PVDF membranes (Amersham). The immunoblots were tested by the standard OKT4 antibody produced by the ATCC cell lines, which were initially grown in the recommended cell culture conditions, but we later modified to grow in sera-free media (ATCC).

For immunoblotting, the enriched fractions of the CD4+ cells were lysed with RIPA. The lysates were electrophoresed by PAGE and validated as immune-precipitated ones.

Alternatively, primarily for future expression of the CD4 selected domains, total mRNA was isolated from these cells and stored. [68-69] After importing the CD4 mRNA main transcripts' sequences from GenBank, the primers flanking the CD4 coding sequence were designed with the aid of 5Prime software (NIH) and synthesized. [SEQ ID NO: 1-5] [23-26] These primers served to create cDNA templates, which were cloned into the plasmids comprising CMV promoter and metal binding domains, hetero-bifunctional linker domains linking chelates. [63-66, 76-77] The choice of the coding cloning vector was contingent upon the future molecule to be rendered superparamagnetic for nuclear magnetic resonance 
diagnosis and for magnetic separation or fluorescent for FCM diagnosis and for FACS separation. Propagated plasmids were electroporated into the human myelomas, which were established from the oncology patients diagnosed with Multiple myelomas, to express the monomeric, soluble CD4. The cells were conditioned to grow in the serum-free RPMI media in roller bottles at $37 \mathrm{deg}$. C, 5\% CO2. Therefore, supernatant could be easily used to test secreted recombinant receptors expressed from all the transcript variant versions by NMR and FCM. [63-64, 76-77]

\section{Human Immunodeficiency Virus gp160, gp120, gp41, p24}

HIV glycoproteins gp160, gp120, gp41, p24, were affinity absorbed from the effusions of the HIV+ oncology patients admitted primarily for treatment of Kaposi sarcomas or from cultures, as well, as transgenically expressed. [23-26, 63-66, 75] Templates were generated by two ways. Total mRNA was isolated from HIV+ producing CD4+ lymphocytes of the HIV+ patients as described. [SEQ ID NO: 6-8] To make gp160, gp120, gp41, p24, total mRNA was converted into ds cDNA by reverse transcription and polymerase chain reaction aided by the primers for coding sequences for gp160, gp120, gp41, p24 having sequences imported from GenBank and synthesized. The yielded amplicons were inserted into plasmids comprising CMV promoters and metal binding coding sequences or bifunctional linker binding domains as in the details described elsewhere. [63, 77] These plasmids were propagated in Escherichia coli grown in Luria-Bartani media on shakers at 37 deg. C. After isolation of plasmids on Maxipreps (Qiagen), the restriction sites were tested and plasmids cut opened to accept the inserts coding for gp160, gp120, gp41. The new plasmids (pCMVgp160, pCMV-gp120, pCMV-gp41, pCMV-p24) were electroporated into the myeloma cells in cultures established from effusions of the oncology patients diagnosed with Multiple myelomas. Either HAT or RPMI1640 based culture media were supplemented with the filtered effusion fluids rather than bovine sera. Alternatively, the HIV proteins were isolated directly from the patients' effusions or cultures by affinity columns or magnetic, activated, molecular sorting (MAMS). [71-72]

\section{Anti-CD4, anti-gp120, anti-gp160, anti-gp41, anti-p24 genomically engineered antibodies (GEAs)}

All HIV+ patients manifested anti-HIV antibodies, which were detected in their blood and lymph with the clinical diagnostic tests. [50] One of these patients manifested also anti-CD4 antibodies. Taking advantage of these laboratory results, we adopted coding sequences from the plasma and B cells of these patients, while using them for biomolecular engineering of genomically engineered anti-virus antibodies (AVAs), which in the process were also rendered magnetic and / or fluorescent. All the procedures of manufacturing of antibodies was pursued as previously described and briefly outlined here. [62-65, 71-72]

The plasma and B cells were selected from blood of the HIV+ patients by MACS and FACS using our anti-CD19 and anti-CD20 magnetic antibodies. [61] Total mRNA was isolated and stored. After importing the human $\mathrm{HC}$ and LC lead conserved sequences [Kabat], the primers were designed with the aid of the 5Prime software [NIH] for heavy and light variable chains and synthesized. [61, 68-69] After reverse transcription, these primers primers served to create cDNA templates, which were cloned into the plasmid containing 
CMV promoter and metal binding domains. Plasmids were propagated in Escherichia coli grown in the Luria-Bartani media in cultures maintained on the shakers at $37 \mathrm{deg}$. C. After purification on MaxiPreps [Qiagen], the plasmids were electroporated into the cells in cultures of myelomas, which were established from the effusions of the oncology patients, who were diagnosed with Multiple myelomas. The cells were cultured in RPMI1640 media, but modified on such a way that they were supplemented with the filtered effusions of the patients, but not bovine sera. Later, the cells were conditioned to grow in serum-free media in roller bottles at $37 \mathrm{deg} \mathrm{C}$ and $5 \% \mathrm{CO}$, and later conditioned to the $\mathrm{CO} 2$-free environment. Therefore, supernatant could be easily used to test specificity of secreted antibodies. Only antibodies with metal binding domains (MBS), were used to attach to superparamagnetic nanoparticles (SPM-CSP). [71-72, 75-76] The binding domains were chosen to provide strong direct binding to $\mathrm{Au}, \mathrm{Ni}, \mathrm{Co}, \mathrm{Fe}$ and / or $\mathrm{Fe}_{3} \mathrm{O}_{4}$ or $\mathrm{SiO}_{2}$ activated shells of core-shell superparamagnetic molecules as outlined herein. [82-83] Metal binding domains (MBS) facilitated rendering them not only superparamagnetic, but also fluorescent, if MBS were saturated with $\mathrm{Eu}$ or $\mathrm{Tb}$.

\section{Superparamagnetic domains and molecules}

Superparamagnetic molecules (SPM) are prepared to comprise solid homogenous or coreshell architecture. The choice of these superparamagnetics is driven by their future applications. The solid superparamagnetic particles are used for in vitro diagnosis and research. The core-shell particles are manufactured for in vivo, in-patients diagnosis and therapy. Their inner core provides superparamagnetic properties. Their outer shells comprise biologically inert elements to protect the patients from potentially leaking, toxic magnetic material and to offer interfacing layer to link them with guiding molecules in VAT. [62, 71$72,68-69,73-74,80-81]$

The solid, homogenous, magnetic nickel and iron metal binding domains / particles are synthesized according to classical protocols modified for this project. [60, 73-77] Therefore, the magnetic properties of genomically engineered molecules (GEM) are gained either by incorporation of superparamagnetic entities into the structure of genomically engineered molecules or by attaching of superparamagnetic particles (SPM) to the genomically engineered molecules. Chemical reactions involved in linking biomolecules and metallic entities are described in the details. [60, 80-81]

The core-shell particles comprise $\mathrm{Fe}_{3} \mathrm{O}_{4}$ or $\mathrm{Ni}$, Co cores and $\mathrm{Au}$ or $\mathrm{SiO}_{2}$ shells engineered according to classical protocols modified for this project. [60] Briefly, the cores are synthesized by mixing aqueous solutions of $\mathrm{FeCl}_{3} \times 6 \mathrm{H}_{2} \mathrm{O} / \mathrm{FeCl}_{2} \times 4 \mathrm{H}_{2} \mathrm{O}$ in $1 / 2$ molar ratio, followed by adding $1 \mathrm{M} \mathrm{NaOH}$ and stirring initially at room temperature, that is gradually increased to $90 \mathrm{deg}$. $\mathrm{C}$ for $1 \mathrm{~h}$. The process is completed by multiple cycles of rinsing with water. The superparamagnetic particles are then retained by magnets and dispersed in water as ferrofluid. The gold shells are prepared according to the modification of the classical Turkevich procedure. [80] The aliquots of the ferrofluid are mixed with $1 \% \mathrm{HAuCl}_{4}$, that is followed by adding $100 \mathrm{mM} \mathrm{NH}_{4} \mathrm{OH}$. The thickness of the shells is determined empirically by monitoring time and changes in absorption at $400 \mathrm{~nm}$ being indicative of depletion of $\mathrm{Au}$. The silica shells are prepared according to the modification of the classical Stober 
procedure. [81] The solution is added to the aliquots of the ferrofluid and multiple cycles of incubation for $1 \mathrm{~h}$ at $90 \mathrm{deg}$. $\mathrm{C}$, those are followed by multiple rinses with water. Covalent attachments of CD4 and anti-gp120 to shells follow. [82-83]

\section{Nuclear magnetic resonance spectroscopy (NMR) Magnetic, activated cell sorting (MACS) Magnetic apheresis}

The cells were labeled with the superparamagnetic antibodies as described in details elsewhere. [62-63, 71-72, 76-77] Briefly, the antibodies were dissolved and all washing steps carried in phenol-free, $\mathrm{Ca}+\mathrm{Mg}+$ - free, PIPES buffered saline solution, supplemented with $20 \mathrm{mM}$ glucose, $10 \%$ human serum. The aliquots were dispensed into the magnetismfree NMR tubes (Shigemi). The relaxation times T1 and T2 were measured in resonance to the applied pulse sequences on the NMR spectrometers: DMX 400 WB, MQ20, MQ60, AVANCE II NMR (Bruker) or the Signa clinical scanners (General Electric).

The VAT aka GEM-SPM or AVA-SPM were used to isolate the labeled molecules and/or cells from the solution. The labeled cells rendered superparamagnetic properties, which facilitated their isolation on the magnetic, activated cell sorter (MACS) operated at $0.47 \mathrm{~T}-$ 9.4 $\mathrm{T}$ and / or clinical MRI instruments operating at $0.5 \mathrm{~T}-3 \mathrm{~T}$ and / or NMR scanners operating at $0.47 \mathrm{~T}-4.7 \mathrm{~T}-9.4 \mathrm{~T}$ (Bruker) (Thanks to the NIH and NSF grant support to $\mathrm{MM})$. Measurements were also performed at T1 and T2 using Bruker mq60 (60 MHz, sample tube $7.5 \mathrm{~mm}$ diameter) and mq20 (20 MHz, sample tube $10 \mathrm{~mm}$ diameter).

Measurements were also validated from performed in the clinical scanners at $1.5 \mathrm{~T}$ and $3 \mathrm{~T}$ (Bruker or GE) with the samples loaded into multiwall plates, imaged, and quantified from the image brightness with ImageJ (NIH). Apheresis of the VAT aka GEM-SPM tagged Human Immunodeficiency Virus (HIV) was conducted on various ways in preparation for research, diagnostic, or clinical applications: external field, magnetic filters, magnetic needles, and magnetic traps.

\section{Flow cytometry (FCM) Fluorescent, activated cell sorting (FACS) Multiphoton spectroscopy}

The cells were labeled with the fluorescent antibodies as described in details elsewhere. [63, 71-72, 79] They were sorted on the Calibur, Vantage SE, or Aria (Becton-Dickinson). The antibodies were dissolved and all washing steps carried in phenol-free, $\mathrm{Ca}+\mathrm{Mg}+-$ free, PIPES buffered saline solution, supplemented with $20 \mathrm{mM}$ glucose, $10 \%$ human serum. Sorting was performed on Aria, Calibur, Vantage SE (Becton-Dickinson) with the sheath pressure set at 20 pounds per square inch and low count rate. The sorted batches were analyzed on Calibur or Aria using FACS Diva software or on the FC500 (Beckman-Coulter). For the measurement of the fluorescently labeled cells, these settings were tuned at the maximum emission for the Eu chelated antibody at $500 \mathrm{~V}$ with references to isotype antibodies and non-labeled cells. This assured the comparisons between populations of cells labeled with multiple antibodies without changing the settings on PMTs.

The fluorescently labeled cells or tissues were imaged with the Axiovert (Zeiss) equipped with the Enterprise argon ion (457 nm, $488 \mathrm{~nm}, 529 \mathrm{~nm}$ lines) and ultraviolet (UV) (364 nm line) lasers; Odyssey XL digital high-sensitivity with instant deconvolution confocal laser 
scanning imaging system operated up to 240 frames/s (Noran), and the Diaphot (Nikon) equipped with the diode-pumped Nd:YLF solid state laser (1048 nm line) (Microlase).

\section{Energy dispersive X-ray spectroscopy (EDXS) Electron energy loss spectroscopy (EELS) $X$-ray reflection fluorescence spectroscopy (XRFS)}

Elemental analyses were pursued by EDXS, EELS, and XRFS as described earlier. [62-63, 71-72, 79] The field emission, scanning transmission, electron microscope FESTEM HB501 (Vacuum Generators) was equipped with the energy dispersive x-ray spectrometer (EDXS) (Noran) and post-column electron energy loss spectrometer (EELS) (Gatan). The cryoenergy filtering transmission electron microscope 912 Omega was equipped with the incolumn, electron energy loss spectrometer (EELS) and the energy dispersive x-ray spectrometer (EDXS) (Zeiss). The cryo-energy filtering transmission electron microscopes 410 and 430 Phillips were equipped with the post-column, electron energy loss spectrometers (EELS) and the energy dispersive x-ray spectrometer (EDXS) (Noran). The field emission, scanning electron microscope SEM1530 (Zeiss) was equipped with the energy dispersive x-ray spectrometer (EDXS) (Noran). The field emission, scanning electron microscope $\mathrm{H} 3400$ (Hitachi) was equipped with the energy dispersive x-ray spectrometer (EDXS) (Hitachi). The S2 Picofox XRFS spectrometer was equipped with a molybdenum (Mo) X-ray target and the Peltier cooled Xflash Silicon Drift Detector (Bruker AXS). Scan times ranged up to 1000 seconds. The ICP standard of $1000 \mathrm{mg} / \mathrm{l}$ of mono-element Gallium or Gadolinium (CPI International) was added to 500 microL of each sample to the final concentration of $10 \mathrm{mg} / \mathrm{l}$. Instrument control, data collection, and analysis were under the SPECTRA 7 software (Bruker).

\section{Virus apheresis tags (VAT)}

The aforementioned CD4 molecules and anti-gp120 antibodies are directly absorbed onto surfaces of the aforementioned superparamagnetic molecules or reacted through bifunctional linkers to the $-\mathrm{SH}$, $-\mathrm{COOH}$, or $-\mathrm{NH} 2$ groups present on surfaces of the aforementioned superparamagnetic molecules to form genomically engineered molecules with superparamagnetic properties (GEM-SPM) in this project specifically named HIVAT. [62$63,76]$

\section{Rapid elimination of HIV from blood and lymph of HIV+ patients}

Removal of HIV was pursued on different ways. First, the VAT aka GEM-SPM tagged samples in metal-free vials were exposed to the uniform, steady magnetic field from $0.47 \mathrm{~T}$ $-9.4 \mathrm{~T}$. The superparamagnetic content of the samples was retained by magnetic field through VAT. The diamagnetic content of these samples was aspirated. Second, the samples were filtered through the polystyrene-coated magnetic gauze inserted into the steady magnetic field from $0.47 \mathrm{~T}-9.4 \mathrm{~T}$. The VAT labeled material was retained by the magnetic field, but non-magnetic flow-through was collected. Thereafter, the VAT-tagged material was immediately released, to separate it from flow-through vials, upon removal from the influence of magnetic field. Third, the VAT-treated blood or lymph was flown over large magnetic surface that was retaining VAT-tagged virus on the flow. Fourth, magnetisminduced needle was inserted into the vials and retracted after a period of time, while pulling out absorbed HIV tagged with VAT. 
Assessment of efficacy was pursued by q-RT-PCR, immunoblotting, immunoprecipitation, and magnetic resonance. [15-16, 21-25, 33, 49, 68-71]

The outcomes were studied on the following ways. First, to determine the HIV count, both, superparamagnetic and diamagnetic materials, but separately, were processed through reverse transcription and polymerase chain reaction as outlined in details in this report. Second, to determine CD4 expression and display, the samples were lysed for processing with RT and PCR aided by the primers, which sequences of the five known transcripts were imported from the GenBank, and synthesized as described in details in this report.

Alternatively, the samples were labeled with superparamagnetic CD4 or anti-gp120 to be quantified by measurements of relaxivities in NMR and after magnetic activated molecular sorting (MAMS) aided pull-out followed by non-denaturing electrophoresis, immunoprecipitation, or immunoblotting.

\section{Statistical analysis}

All the measurements were run in triplicates for each sample from six patients. The numbers were analyzed and displayed using statistical analysis and image quantification software (GraphPad, ImageJ). Data were presented as mean of standard error of the mean (SEM). Statistical significance was calculated by t-test for two groups.

\section{RESULTS}

\section{Elemental composition of virus apheresis tags (VAT)}

The key elements for success of the HIV apheresis by virus apheresis tags (VAT) were their superparamagnetic properties. These properties were determined by the core-shell $\mathrm{Fe}_{3} \mathrm{O}_{4}{ }^{-}$ $\mathrm{SiO} 2$ or $\mathrm{Fe}_{3} \mathrm{O}_{4}$-Au nanoparticles; thus contingent upon their elemental composition of the magnetic cores. Moreover, the essential element of their safety was presence of bio-neutral shells. They were meant to prevent cores' content against leaking to the environment. That was determined by studying elemental composition of their shells. The elemental composition of superparamagnetic VAT was determined by Energy Dispersive X-ray Spectroscopy as displayed in FIG. 1. The sharp, multiple energy peaks for Fe, O, of the $\mathrm{Fe}_{3} \mathrm{O}_{4}$ cores and $\mathrm{Si}, \mathrm{O}$ of the $\mathrm{SiO}_{2}$ shells clearly confirm the desired elemental composition. The designed elemental composition of $\mathrm{Fe}_{3} \mathrm{O}_{4}$ - $\mathrm{Au}$ nanoparticles was confirmed the same way.

\section{VAT specificity and sensitivity to tag HIV}

The ultimate test for this endeavor was to determine, if indeed VAT would be specific and sensitive enough for pulling specifically HIV out of blood or lymph acquired from the HIV+ patients. The outcomes would have to be compared versus naïve, healthy donors, or the patients carrying other viral diseases (e.g., HBV, HPV, HSV, CMV). Efficacy of VAT is obviously contingent upon specificity and sensitivity of their guiding domains: CD4 and anti-gp120 to tag gp120 - the lead targeting molecule of HIV. To determine that, blood or lymph of healthy donors, the HIV+ patients, and the $\mathrm{HBV}+$ patients were having administered CD4 and anti-gp120 guided HIVAT, spun down at 1000g to remove cells, debris, and aggregates, followed by affinity columns saturated with non-competing, non- 
neutralizing anti-gp120, and elution. Lysates and eluates were transferred all onto PVDF membranes, and labeled with the CD4 and anti-gp120 as shown in FIG. 2. Therefore, the only source of gp120 could come from apheretic acquisition of HIV. Both VAT were derivatized with nickel, cobalt, or iron nanoparticles. Only gp120 was labelled very specifically, so that it appeared as one, single band on the PVDF membrane, while the remaining portions of the lanes entirely and completely clear. The lanes carrying lysates from healthy donors and HBV+ patients, as well as mutated CD4 and gp120 remained bands' free. Intensity of the bands was contingent upon the concentration of gp120; thus indicative of gravity of the HIV viremia.

\section{Efficacy VAT aided HIV apheresis from blood and lymph of HIV+ patients}

The VAT aided efficacy test was meant to determine, if indeed VAT would be capable for pulling most, if not all, of HIV out of blood or lymph acquired from the HIV+ patients. The easiest and the fastest ways to monitor viremia and efficacy of apheresis are accomplished by measuring relaxation time rates in NMR or MRI. [72, 79] To determine that, CD4 and anti-gp120 guided VAT aka HIVAT was administered into blood or lymph of the HIV+ patients, spun down at $1000 \mathrm{x} g$ to remove cells, debris, and clusters, followed by affinity columns saturated with non-neutralizing, non-competing anti-gp120, and elution. Relaxation time rate changes induced by VAT bound to HIV were recorded in NMR after separating each into 2 separate vials: one containing HIV apheresed by VAT and the other non-bound eluates. This approach allowed us to quantify efficacy of HIVAT aided apheresis (apheresed to non-apheresed ratio) as reported in FIG. 3. Relaxivities for water, blood, and serum of healthy volunteers served as the additional controls. In assessment of the results, it is very important to realize that relaxation time rates are contingent upon many factors including, but not limiting to field strength, frequency, relaxivity, molecular weight, binding constants, etc. Therefore, setting the base line measurements for water, serum, lymph and blood are essential, as well multiple controls performed by measuring relaxation times for healthy donors, as well as after administrating of VAT engineered with mutated CD4 or isotype antigp120, and also being tested on the other viruses having the completely different targeting molecule e.g., HBV. The readings are then relative to these base line values. Further, they can be then correlated to q-RT-PCR data, to make NMR data additionally validated quantitatively. As shown, VAT are sensitive and specific as an effective treatments in various disease gravity measures, in all heights of the HIV viremia. As the data show, the HIVAT was primarily contingent upon the molar ratios of HIVAT. With the sufficiently high dose of HIVAT, it could eliminate the HIV from blood and lymph of HIV+ patients, so that HIV was not detected by immunoblotting, q-RT-PCR, and NMR. The data demonstrate rapid reduction of the HIV viremia in blood of the HIV+ patients thanks to administration of VAT, specifically HIV targeting genomically engineered molecules engineered with superparamagnetic properties (GEM-SPM) aka Human Immunodeficiency Virus Apheresis Tags (HIVAT).

\section{Dose dependence of elimination of HIV viremia from blood and lymph of HIV+ patients}

Rapid reduction of the HIV viremia in blood of the HIV+ patients thanks to administration of VAT, specifically Human Immunodeficiency Virus Apheresis Tags (HIVAT) aka genomically engineered molecules engineered with superparamagnetic properties (GEM- 
SPM) is presented in FIG. 4. The GEM portions of VAT comprise recombinant CD4 or antigp120. Therefore, they are uniquely and reliably specialized in docking the HIV through its gp120 infection lead. The SPM portions of VAT comprise superparamagnetic domains. Therefore, they efficiently aid retention of HIV, anchored through its gp120 docked into CD4 of VAT, by magnetic field. Efficacy of this apheresis is contingent upon the ratio between the number of HIV in blood or lymph and the number of VAT administered to the specific sample. The higher the viremia the higher the number of VAT has to be administered to reduce the viremia. The higher the viremia the more rounds of VAT administration are necessary to bring down the viral count to undetectable levels. Equivalent results were acquired for treatment of lymph with VAT. Although, the antibodies linked to form VAT were nearly as effective as the CD4 guided ones. However ultimately, the efficacy of the HIV rapid removal is primarily contingent upon the gravity of HIV viremia (HIV particle counts) versus dose (VAT particle count) and regimen (maintaining or frequency of VAT guided aphereses).

\section{Long term repression of HIV viremia}

Rapid reduction of the viral count has long term consequence for the height of the HIV viremia in time (thus corresponding to the time frame of progression of the disease towards AIDS) as shown in FIG. 5. The presented results compare how viremia, in blood acquired from the HIV+ patients and maintained in cultures, progresses in absence of administration of VATs and how it is repressed thanks to the daily administration VATs and apheresis. Without administration of VAT aka GEM-SPM, viremia may reach $10^{\wedge} 8$ copies in a milliliter of blood or lymph in a few weeks. With administration of VAT and VAT, the HIV viremia is repressed down to only a few hundred copies of HIV or undetectable by PCR levels contingent upon the concentration and number of cycles of the administered VAT aka GEM-SPM.

\section{Prophylactic administration of VAT reducing raise of HIV viremia}

Human Immunodeficiency Virus Apheresis Tags (HIVAT) have also preventive effects onto the progress of the HIV viremia as shown in FIG. 6. These effects were revealed, when the human CD4+ lymphocytes in cultures with or without VATs were spiked with 100 copies of HIV adjusted in 100 microliter of blood or lymph from the HIV+ patients. In a week, the HIV copy number in culture without VAT increased to a few thousand copies. During the same time, the HIV copy number in the culture containing VAT prior to infection and treated by cycles of magnetic apheresis was retained at very low, down to PCR undetectable levels.

\section{HIVAT repression of new infections of CD4+ cells}

Reducing the HIV viremia thanks to administration of HIVATs resulted in the dramatic reduction of the newly infected CD4+ lymphocytes as shown in FIG. 7. The graph shows, that the number of CD4+ newly infected was significantly lower in the samples in which HIVAT were applied, than in the samples in which its administration was absent. Therefore, VAT were very effective decoys protecting CD4+ cells against being infected by HIV. 


\section{VAT aided, long term protection of the CD4+ cells' population}

Progression of the HIV infection into AIDS is primarily driven by the cytopathic effects upon CD4+ cells. Administration of VAT caused the dramatic improvement of the CD4+ cells' population as demonstrated in the FIG. 8. The CD4+ cell counts in blood and lymph cultures acquired from the healthy donors were quickly depleted upon the HIV infection with 100 microliters of the blood or lymph from the HIV+ patients. However, when the parallel samples were treated with HIVAT followed by daily sessions of apheresis and replenishing of fresh batches of VAT, populations of the CD4+ cells were retained near borders of the low norm levels. Relevance of this procedure to the clinical practice would be giving the time for the infected patients' immune system to assemble immune response; thus surely reduce progression of the disease.

\section{DISCUSSION}

Since the patients' infection with HIV, the viral count rapidly increases up to $10^{\wedge} 8$ copies per milliliter or $10^{\wedge} 5$ per microliter of plasma in $4-6$ weeks. [1-3] This is associated with rapid decrease of the $\mathrm{CD} 4+$ cell population down to 500 or $5 \times 10^{\wedge} 2 \mathrm{CD} 4+\mathrm{T}$ lymphocytes per microliter of blood during the same period of time. This makes more than 200 copies of HIV per $1 \mathrm{CD} 4+$ cell, which have to be annihilated to prevent continued infections.

Cytopathic effects, which result from HIV hijacking of the CD4+ molecular mechanisms for replication are the underlying pathomechanisms. Briefly, the following chain of events takes place, the higher HIV viral count, the more CD4 cells become infected, the more CD4 cells die, the more immunocompromised patients become, the more rapid progression of AIDS these patients suffer from, the more likely opportunistic infection strike, and the earlier the patients die. Therefore, in our opinion, the primary, the most essential element of any therapy of the patients infected with HIV should be, to repress the number of HIV in blood and lymph, from the earliest stages of this infectious disease through all stages of advancing disease to death. In clinical practice, the goal should be to maintain viremia at the lowest levels, not only by chemotherapeutic inhibition of molecular mechanisms of the CD4+ cells, but primarily by physical reduction of the viral particles from the earliest stages of the HIV infection. Yet, no such procedure existed to date. This is exactly, what we have accomplished by designing and manufacturing VAT aka HIVAT in this project. Administration of HIVAT into blood and lymph acquired from the HIV+ patients resulted in eliminating viremia or at least reducing it down to the levels undetectable by the most sensitive tests to date: q-RT-PCR, immunoblotting, and NMR. As our data show, we can efficiently reduce the HIV viremia in blood and lymph of the HIV+ patients with high specificity and high sensitivity, but also repress it to low levels, while monitoring the therapeutic efficacy of HIVAT.

In addition to viremia, HIV are hiding within cells, replicate in them, and propagate through cytopathosis, budding, and syncytia. Repressing these processes is the purpose of administering various cocktails of chemotherapies. However, these strategies do not eliminate physically the HIV infected cells. Therefore, complementary to HIVAT, we have developed the procedure eliminating the HIV infected cells. [8] Nevertheless, both novel 
approaches can well support chemotherapies currently approved; thus they can complement each other.

Magnetic forces involved in the interactions of the VAT superparamagnetic domains with fields of the magnets are decisive factors for efficacy of the virus apheresis. Herein, we presented only the part pertinent to apheresis of HIV. These forces will differ, if applied for VAT having different relaxivities, other viruses, and magnetic fields having different strengths. In those realms, the aforementioned factors have to be calibrated accordingly, the same way as we have them calibrated herein. [60, 73-74, 77]

We propose streamlining of VAT administration for elimination of HIV viremia within different clinical trials' scenarios. First, VAT may be used in addition to HAART, while most likely allowing us to reduce the doses of administered chemotherapeutics. Second, if administered pre-emptively, they may potentially work as prophylactic vaccine. Third, for patients, who are contraindicated to receive the chemotherapy, VAT may become their main rescue route. Successful completion of the clinical trials in this regard would pave the road for streamlining this approach as therapy into medical practice.

In preparation to streamlining of VAT into the clinical trials, we consider safety of the participants as the most important factor. Adverse effect may differ contingent upon the VAT guiding domain: human CD4 versus anti-gp120. Human CD4 is the molecule omnipresent on the T helper class of lymphocytes. It is expressed through 5 splicing mRNA variants. The CD4 docking domain is fairly conserved. Any mutants of this domain, the same way as of CXCR5, makes the person carrying them resistant to the HIV infection. Therefore, these people can be withdrawn from the HIV vaccination and vaccine based therapy based upon simple pharmacogenomic tests. Moreover, VAT can be personalized, while taking the CD4 sequence from the patient qualified for VAT therapy. Anti-gp120 antibodies may become immunogenic, if incorporated as VAT guiding domains. This is the same way as therapeutic human and / or humanized antibodies may raise HAHA. Mouse antibodies, even after being humanized, may still often lead to HAMA. So can antibodies from other species. All of them may annihilate therapeutic efficacy and cause adverse effects. For those reasons, immunotherapy is often preceded by immunosuppressants. Moreover, classes of anti-gp120 will also affect potential adverse effect due to immunogenicity depending, if $\operatorname{IgG}, \operatorname{IgG} / 2$, $\mathrm{Fab}, \mathrm{scFv}$, diFv, or dcFv. Thereafter, promoting HIV infections by anti-HIV antibodies was already reported. Furthermore, the polyvalent antibodies may also result in formation of aggregates with severe adverse consequences depending if HIV apheresis is initiated extraor intra-corporeally.

Finally, the data which we have presented here are so encouraging and the procedures so simple to adjust, that can be easily adapted by a person skilled in pharmaceutical biotechnology, cell molecular biology, and genomic medicine, as treatments of viremias perpetrated by other deadly viruses. 


\section{CONCLUSIONS}

Herein, we present the new, effective treatment with virus apheresis tags (VAT), specifically Human Immunodeficiency Virus Apheresis Tags (HIVAT), of the HIV+ patients' blood and lymph, which is eliminating the HIV viremia.

It can be easily adapted as treatments of viremias perpetrated by other deadly viruses, which we vigorously pursue.

\section{Supplementary Material}

Refer to Web version on PubMed Central for supplementary material.

\section{ACKNOWLEDGEMENTS}

\footnotetext{
The consent of the patients to use their samples is gratefully acknowledged with thanks. Provision of some of the samples by Dr. J. Pietruszkiewicz, Dr. J. Szymendera, Dr. J. Steffen, is gratefully acknowledged with thanks. Access to the NMR spectrometers at the NMRFAM and Bruker, clinical magnetic imagers at Radiology Departments at AMC and MSCMCC, and high throughput sequencers and synthesizers at Biotechnology Centers at SDSU, UW, and NIH to perform independent validation of the results is confirmed. Technical assistance in performing tests on non-infectious samples by A. Faroohar, A. Sun, B. Redka, C. Dodivenaka, C. Quach, C. Sabo, D. Pogorzelska, E. Putzer, J. Dahlke, M. Haig, N. Takeuchi, S. Nagel is greatly appreciated. Discussions with Dr. Z. Darzynkiewicz, Dr. J. Edgerton, Dr. J. Langmore, Dr. M.P. Lefranc, Dr. J. Markley, Dr. S. Sidhu, Dr. W. Szybalski, are recognized.

The Authors declare no conflict of interest.
}

\section{Abbreviations}

HIV

AIDS

SPM

CD4

gp120

gp160

gp41

NKC

CTL

EDXS

EELS

XRFS

FCM

NMR
Human Immunodeficiency Virus

Acquired Immunodeficiency Syndrome

superparamagnetic

Cluster of Differentiation 4

glycoprotein 120

glycoprotein 160

glycoprotein 41

natural killer cell

cytotoxic lymphocyte

energy dispersive $\mathrm{x}$-ray spectroscopy

electron energy loss spectroscopy

$\mathrm{x}$-ray reflection fluorescence spectroscopy

flow cytometry

nuclear magnetic resonance 
14. Daar ES, Moudgil T, Meyer RD, Ho DD. Transient high levels of viremia in patients with primary human immunodeficiency virus type 1 infection. N Engl J Med. 1991; 324(14):961-4. [PubMed: 1823118]

15. Graziosi C, Pantaleo G, Butini L, Demarest JF, Saag MS, Shaw GM, Fauci AS. Kinetics of human immunodeficiency virus type 1 (HIV-1) DNA and RNA synthesis during primary HIV-1 infection. Proc Natl Acad Sci U S A. 1993; 90(14):6405-9. [PubMed: 8341646]

16. Menzo S, Bagnarelli P, Giacca M, Manzin A, Varaldo PE, Clementi M. Absolute quantitation of viremia in human immunodeficiency virus infection by competitive reverse transcription and polymerase chain reaction. J Clin Microbiol. 1992; 30(7):1752-1757. [PubMed: 1629331]

17. Ho DD, Moudgil T, Alam M. Quantitation of human immunodeficiency virus type 1 in the blood of infected persons. N Engl J Med 1989; 321:1621-1625. [PubMed: 2586564]

18. Schnittman SM, Psallidopoulous MC, Lane HC. The reservoir for HIV-1 in human peripheral blood is a T cell that maintains expression of CD4. Science 1989; 245:305-8. [PubMed: 2665081]

19. Cummins NW, Badley AD. Mechanisms of HIV-associated lymphocyte apoptosis: 2010. Cell Death Dis. 201011 11;1:e99. [PubMed: 21368875]

20. Dagleish AG, Beverly PCL, Clapham PR, Crawford DH, Greaves MF, Weiss RA. The CD4 (T4) antigen is an essential component of the receptor for the AIDS retrovirus. Nature 1983; 312: $763-$ 765.

21. Sodroski J, Goh WC, Rosen C, Campbell K, Haseltine W. Role of HTLV-III/LAV envelope in syncytium formation and cytopathicity. Nature 1986; 322:470-474. [PubMed: 3016552]

22. El-Farrash MA, Harada S. Syncytium-Inducing Capacity of Human Immunodeficiency Virus (HIV): Analysis by the Use of Cloned Viruses. Microbiol. Immunol. 1989; 33: 549-559. [PubMed: 2505024]

23. Zhang LQ, MacKenzie P, Cleland A, Holmes EC, Brown AJ, Simmonds P. Selection for specific sequences in the external envelope protein of human immunodeficiency virus type 1 upon primary infection. J Virol. 1993; 67(6):3345-56. [PubMed: 8497055]

24. Yourno J, Conroy J. A novel polymerase chain reaction method for detection of human immunodeficiency virus in dried blood spots on filter paper. J Clin Microbiol. 1992; 30(11):288792. [PubMed: 1452659]

25. van Bueren J, Simpson RA, Jacobs P, Cookson BD. Survival of human immunodeficiency virus in suspension and dried onto surfaces. J Clin Microbiol. 1994; 32(2):571-4. [PubMed: 8150980]

26. Yourno J Direct polymerase chain reaction for detection of human immunodeficiency virus in blood spot residues on filter paper after elution of antibodies: an adjunct to serological surveys for estimating vertical transmission rates among human immunodeficiency virus antibody-positive newborns. J Clin Microbiol. 1993; 31(5):1364-1367. [PubMed: 8501243]

27. Mulder J, McKinney N, Christopherson C, Sninsky J, Greenfield L, Kwok S. Rapid and simple PCR assay for quantitation of human immunodeficiency virus type 1 RNA in plasma: application to acute retroviral infection. J Clin Microbiol. 1994; 32(2):292-300. [PubMed: 8150937]

28. Gaines H, Albert J, von Sydow M, Sönnerborg A, Chiodi F, Ehrnst A, Strannegård O, Asjö B. HIV antigenaemia and virus isolation from plasma during primary HIV infection. Lancet. 1987; 1(8545):1317-8. [PubMed: 2884436]

29. Chess Q, Daniels J, North E, Macris NT. Serum immunoglobulin elevations in the acquired immunodeficiency syndrome (AIDS): IgG, IgA, IgM, and IgD. Diagn Immunol. 1984; 2(3):14853. [PubMed: 6499376]

30. Goudsmit J, Miedema F, Wijngaarden-du Bois RJ, Roos MT, Schellekens PT, Coutinho RA, van der Noordaa J, Melief CJ. Immunoglobulin subclasses of antibodies to human T-cell leukemia/ lymphoma virus I-associated antigens in acquired immune deficiency syndrome and lymphadenopathy syndrome. J Virol. 1985; 53(1):287-291. [PubMed: 2981348]

31. Aiuti F, Rossi P, Sirianni MC, Carbonari M, Popovic M, Sarngadharan MG, Contu L, Moroni M, Romagnani S, Gallo RC. IgM and IgG antibodies to human T cell lymphotropic retrovirus (HTLVIII) in lymphadenopathy syndrome and subjects at risk for AIDS in Italy. Br Med J (Clin Res Ed). 1985; 291(6489):165-6 
32. Gaines H, von Sydow M, Sönnerborg A, Albert J, Czajkowski J, Pehrson PO, Chiodi F, Moberg L, Fenyö EM, Asjö B, Forsgren M. Antibody response in primary human immunodeficiency virus infection. Lancet. 1987; 1(8544):1249-53. [PubMed: 2884379]

33. Kenealy W, Reed D, Cybulski R, Tribe D, Taylor P, Stevens C, Matthews T, Petteway S. Analysis of human serum antibodies to human immunodeficiency virus (HIV) using recombinant Env and Gag antigens. AIDS Res Hum Retroviruses. 1987; 3(1):95-105. [PubMed: 3304356]

34. Sarngadharan MG, Popovic M, Bruch L, Schüpbach J, Gallo RC. Antibodies reactive with human T-lymphotropic (HTLV-Ill) in the serum of patients with AIDS. Science. 1984; 224:506-508. [PubMed: 6324345]

35. Geroldi D, Aricò M, Plebani A, Maccario R, Notarangelo LD, Duse M, Rey F, Barrè Sinoussi F, Chermann JC, Burgio GR. Western blot technique in the serological evaluation of three LAV/ HTLV III-infected Italian families. Infection. 1986; 14(2):60-3. [PubMed: 3011677]

36. NIH. AIDS. Fact sheet - Therapeutic vaccine. https://aidsinfo.nih.gov/understanding-hiv-aids/factsheets/19/91/what-is-a-therapeutic-hiv-vaccine-downloaded06DEC2017

37. Traunecker A1, Lüke W, Karjalainen K. Soluble CD4 molecules neutralize human immunodeficiency virus type 1. Nature. 1988; 331(6151): 84-6. [PubMed: 2829024]

38. Fisher RA, Bertonis JM, Meier W, Johnson VA, Costopoulos DS, Liu T, Tizard R, Walker BD, Hirsch MS, Schooley RT, Flavell RA. HIV infection is blocked in vitro by recombinant soluble CD4. Nature. 1988; 331(6151): 76-78. [PubMed: 2829022]

39. Bruel T, Guivel-Benhassine F, Amraoui S, Malbec M, Richard L, Bourdic K, Donahue DA, Lorin V, Casartelli N, Noël N, Lambotte O, Mouquet H, Schwartz O. Elimination of HIV-infected cells by broadly neutralizing antibodies. Nature Communications. 2016; 3; 7:10844.

40. Hua CK, Ackerman ME. Increasing the clinical potential and applications of anti-HIV antibodies. Front Immunol. 2017; 8:1655. [PubMed: 29234320]

41. Hodges TL, Kahn JO, Kaplan LD, Groopman JE, Volberding PA, Amman AJ, Arri CJ, Bouvier LM, Mordenti J, Izu AE. 1991. Phase 1 study of recombinant CD4-Immunoglobulin G therapy of patients with AIDS. Antimrobial Agents and Chemotherapy. 1991; 35 (12): 2580-2586.

42. Arthos J, Cicala C, Steenbeke TD, Chun TW, Dela Cruz C, Hanback DB, Khazanie P, Nam D, Schuck P, Selig SM, Van Ryk D, Chaikin MA, Fauci AS. Biochemical characterization of dodecameric CD4-Ig fusion protein. J. Biol. Chem. 2002; 277(130): 11456-11464. [PubMed: 11805109]

43. Bosch B, Blanco J, Pauls E, Clotet-Codina I, Armand-Ugón M, Grigorov B, Muriaux D, Clotet B, Darlix JL, Esté JA. Inhibition of coreceptor-independent cell-to-cell human immunodeficiency virus type 1 transmission by a CD4-immunoglobulin G2 fusion protein. Antimicrob Agents Chemother. 2005; 49(10):4296-304. [PubMed: 16189111]

44. Yu S, Yao Y, Xiao H, Li J, Liu Q, Yang Y, Adah D, Lu J, Zhao S, Qin L, Chen X. Simultaneous Knockout of CXCR4 and CCR5 Genes in CD4+ T Cells via CRISPR/Cas9 Confers Resistance to Both X4- and R5-Tropic Human Immunodeficiency Virus Type 1 Infection. Hum Gene Ther. 2018; 29(1):51-67. [PubMed: 28599597]

45. Liu Z, Chen S, Jin X, Wang Q, Yang K, Li C, Xiao Q, Hou P, Liu S, Wu S, Hou W, Xiong Y, Kong C, Zhao X, Wu L, Li C, Sun G, Guo D. Genome editing of the HIV co-receptors CCR5 and CXCR4 by CRISPR-Cas9 protects CD4+ T cells from HIV-1 infection. Cell Biosci. 2017;7:47 [PubMed: 28904745]

46. Hou P, Chen S, Wang S, Yu X, Chen Y, Jiang M, Zhuang K, Ho W, Hou W, Huang J, Guo D. Genome editing of CXCR4 by CRISPR/cas9 confers cells resistant to HIV-1 infection. Sci Rep. 2015; 5:15577. [PubMed: 26481100]

47. Li C, Guan X, Du T, Jin W, Wu B, Liu Y, Wang P, Hu B, Griffin GE, Shattock RJ, Hu Q. Inhibition of HIV-1 infection of primary CD4+ T-cells by gene editing of CCR5 using adenovirus-delivered CRISPR/Cas9. J Gen Virol. 2015; 96(8):2381-93. [PubMed: 25854553]

48. Nerys-Junior A, Braga-Dias LP, Pezzuto P, Cotta-de-Almeida V, Tanuri A Comparison of the editing patterns and editing efficiencies of TALEN and CRISPR-Cas9 when targeting the human CCR5 gene. Genet Mol Biol. 2018; 41(1):167-179. [PubMed: 29583154]

49. NIH. AIDS. Fact sheet - Guidelines for the Use of Antiretroviral Agents in Adults and Adolescents Living with HIV https://aidsinfo.nih.gov/drugsdownloaded06DEC2017 
50. NIH. AIDS. Fact sheet - HIV medicines and side effects. https://aidsinfo.nih.gov/understandinghiv-aids/fact-sheets/22/63/hiv-medicines-and-side-effectsdownloaded06DEC2017

51. NIH. AIDS. Guidelines. Laboratory Testing for Initial Assessment and Monitoring of Patients with HIV Receiving Antiretroviral Therapy. https://aidsinfo.nih.gov/guidelines/html/1/adult-andadolescent-arv/3/tests-for-initial-assessment-and-follow-updownloaded06DEC2017

52. Cummins NW, Sainski AM, Natesampillai S, Bren GD, Badley AD. Choice of antiretroviral therapy differentially impacts survival of HIV-infected CD4 T cells. Mol Cell Ther. 2014; 2:1.

53. Papaevangelou G, Economidou J, Kallinikos J, Choreimi H, Mandalaki T, Stratigos J, Geroldi D, Barre-Sinoussi F, Chermann JC, Montagnier L. Lymphadenopathy associated virus in AIDS, lymphadenopathy associated syndrome, and classic Kaposi patients in Greece. Lancet. 1984; 2(8403):642.

54. O'Brien RF1, Cohn DL. Serosanguineous pleural effusions in AIDS-associated Kaposi's sarcoma. Chest. 1989; 96(3):460-466. [PubMed: 2766805]

55. Barré-Sinoussi F, Chermann JC, Rey F, Nugeyre MT, Chamaret S, Gruest J, Dauguet C, Axler-Blin C, Vézinet-Brun F, Rouzioux C, Rozenbaum W, Montagnier L. Isolation of a T-lymphotropic retrovirus from a patient at risk for acquired immune deficiency syndrome (AIDS). Science. 1983; 220(4599):868-871. [PubMed: 6189183]

56. Gallo RC, Sarin PS, Gelmann EP, Robert-Guroff M, Richardson E, Kalyanaraman VS, Mann D, Sidhu GD, Stahl RE, Zolla-Pazner S, Leibowitch J, Popovic M. Isolation of human T-cell leukemia virus in acquired immune deficiency syndrome (AIDS). Science. 1983; 220(4599):865-867. [PubMed: 6601823]

57. Popovic M, Sarngadharan MG, Read E, Gallo RC. Detection, isolation, and continuous production of cytopathic retroviruses (HTLV-III) from patients with AIDS and pre-AIDS. Science. 1984; 224(4648):497-500. [PubMed: 6200935]

58. Ehrnst A1, Sönnerborg A, Bergdahl S, Strannegård O. Efficient isolation of HIV from plasma during different stages of HIV infection. J Med Virol. 1988; 26(1):23-32. [PubMed: 3053989]

59. HIV Culture Manual. Berkeley, CA, California State Health Department, 1986.

60. Gallo D, Kimpton JS, Dailey PJ. Comparative studies on use of fresh and frozen peripheral blood lymphocyte specimens for isolation of human immunodeficiency virus and effects of cell lysis on isolation efficiency. J Clin Microbiol. 1987; 25(7):1291-4. [PubMed: 2440906]

61. Gallo D, Kimpton JS, Johnson PJ. Isolation of human immunodeficiency virus from peripheral blood lymphocytes stored in various transport media and frozen at -60 degrees C. J Clin Microbiol. 1989; 27(1):88-90. [PubMed: 2913040]

62. Malecki M, Hsu A, Truong L, Sanchez S. Molecular immunolabeling with recombinant singlechain variable fragment ( $\mathrm{scFv}$ ) antibodies designed with metal binding domains. Proc. Natl. Acad. Sci. U. S. A. 2001; 99: 213-219. [PubMed: 11756693]

63. Malecki M, Szybalski W. Isolation of single, intact chromosomes from single, selected ovarian cancer cells for in situ hybridization and next generation sequencing. Gene. 2012; 493(1): 132139. [PubMed: 22155315]

64. Szybalska EH, Szybalski W. Genetics of human cell line. IV. DNA-mediated heritable transformation of a biochemical trait. Proc. Natl. Acad. Sci. U.S.A. 1962; 48: 2026-2034. [PubMed: 13980043]

65. Chomczynski P, Sacchi N. Single-step method of RNA isolation by acid guanidinium thiocyanatephenol-chloroform extraction. Anal. Biochem 1987; 162:156-159. [PubMed: 2440339]

66. Alizon M, Sonigo P, Barré-Sinoussi F, Chermann JC, Tiollais P, Montagnier L, Wain-Hobson S. Molecular cloning of lymphadenopathy-associated virus. Nature. 1984; 312(5996):757-60. [PubMed: 6096717]

67. Wain-Hobson S, Sonigo P, Danos O, Cole S, Alizon M. Nucleotide sequence of the AIDS virus, LAV. Cell. 1985; 40(1):9-17. [PubMed: 2981635]

68. Wong-Staal F, Gallo RC, Chang NT, Ghrayeb J, Papas TS, Lautenber VER JA, Pearson ML, Petteway SR, Jr., Ivanoff L, Baumeister K, Whitehorn EA, Rafalski JA, Doran ER, Josephs SJ, Starcich B, Livak KJ, Patarca R, Haseltine WA, Ratner L. Complete nucleotide sequence of the AIDS virus, HTLV-III Nature. 1985; 313 (6000): 277-284. 
69. Maddon JP, Molineaux SE, Maddon DE, Zimmerman KA, Godfrey M, Alt FW, Chess L, Axel R. Structure and expression of the human and mouse T4 genes. Proc. Natl. Acad. Sci. U.S.A. 1987; 84:9155-9159. [PubMed: 3501122]

70. Malecki M, Putzer E, Caroline Quach C, Dodivenaka C, Tombokan X. Novel paradigm for immunotherapy of breast cancer by engaging prophylactic immunity against hepatitis B. Clin. Trans. Med. 2016; 5(32):1-12.

71. Malecki M, Sabo C, Foorohar A, Tombokan X. Novel paradigm for immunotherapy of ovary cancer by engaging prophylactic immunity against hepatitis B. Clin Trans Med 2016; 5(44):1-16.

72. Lee MH, Sano K, Morales FE, Imagawa DT. Sensitive reverse transcriptase assay to detect and quantitate human immunodeficiency virus. J Clin Microbiol 1987; 25:1717-1721. [PubMed: 2443532]

73. Gupta P, Balachandran R, Grovit K, Webster D, Rinaldo C, Jr. Detection of human immunodeficiency virus by reverse transcriptase assay, antigen capture assay, and radioimmunoassay. J Clin. Microbiol. 1987; 25:1122-1125. [PubMed: 2439537]

74. Pyle SW1, Bess JW, Jr, Robey WG, Fischinger PJ, Gilden RV, Arthur LO. Purification of 120,000 dalton envelope glycoprotein from culture fluids of human immunodeficiency virus (HIV)-infected H9 cells. AIDS Res Hum Retroviruses. 1987; 3(4):387-400. [PubMed: 2833915]

75. Malecki M HER2/neu gene expression products evaluated with superparamagnetic single chain variable fragment (scFv) antibodies. Proc S Dak Acad Sci. 2007; 86:297-308 [PubMed: 23293401]

76. Glazer JK, Malecki M, Grist TM. Targeted MRI Contrast Agent Using Bioengineered scFv Fragments with Gadolinium Labelled Metal Binding Domain. INSRM 2004; 12: 001713

77. Söffge F, von Hörsten W. Ac-susceptibility measurements in small fields on fine superparamagnetic nickel particles. Zeitschrift für Physik B Condensed Matter. 1981; 42: 47-55.

78. Molday RS, Yen SPS, Rembaum A Application of magnetic microspheres in labelling and separation of cells. Nature. 1977; 268: 437-438. [PubMed: 302417]

79. Malecki M, L'Vanne K, Truong L, Hsu A, Hogan C, Albrecht R. Supramolecular Imaging of Immunolabeling with STEM EDX \& EEL SI Microscopy and Microanalysis. 2004; 10(S02): 1216-1217.

80. Turkevich J, Stevenson PC, Hillier J. A study of the nucleation and growth processes in the synthesis of colloidal gold. Discussions of the Faraday Society. 1951; 11: 1-7.

81. Stöber W, Fink A, Bohn, E. Controlled growth of monodisperse silica spheres in the micron size range. Journal of Colloid and Interface Science. 1951; 26 (1): 62-69.

82. Krejcarek GE, Tucker KL. Covalent attachment of chelating groups to macromolecules. Biochem. Biophys. Res. Commun. 1977; 77(2): 581-585. [PubMed: 409400]

83. Meares CF, Goodwin DA, Leung CS, Girgis AY, Silvester DJ, Nunn AD, Lavender PJ. Covalent attachment of metal chelates to proteins: the stability in vivo and in vitro of the conjugate of albumin with a chelate of 111 indium. Proc Natl Acad Sci U S A. 1976; 73(11): 3803-6. [PubMed: 825856] 


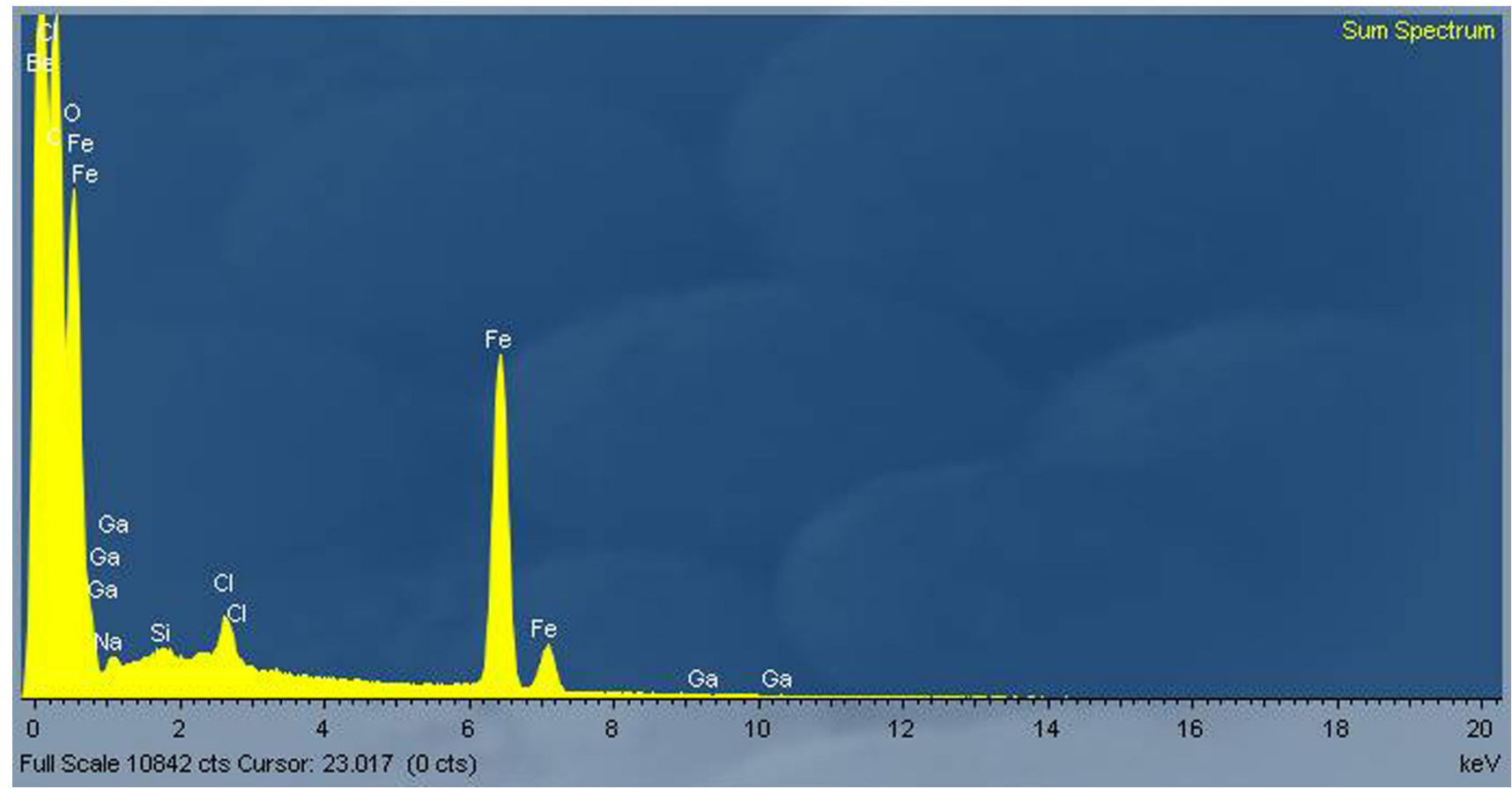

FIG. 1.

Elemental composition of VAT: HIVAT: CD4- $\mathrm{SiO}_{2}-\mathrm{Fe}_{3} \mathrm{O}_{4}$ was determined with EDXS. Energy elemental peaks are marked ( $\mathrm{Fe}$ - iron; $\mathrm{C}$ - carbon; $\mathrm{Si}$ - silica; O- oxygen; $\mathrm{Ga}$ gallium from NIST spiked in, as the internal control). This is a raw read-out, no postacquisition manipulation, from the EDXS machine. 

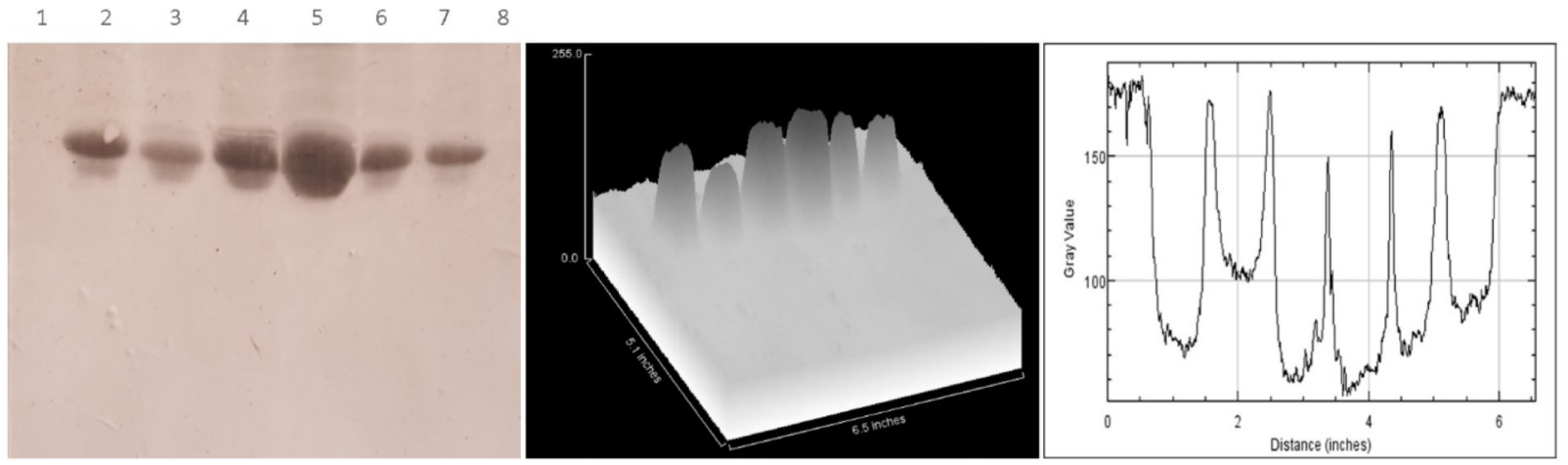

FIG. 2.

Left pane. Immunoblot of electrophoresed and transferred lysates captured by VAT from the healthy donor 1 loaded into the lane 1, the HIV+ patients (2- 7), lanes 4-5 (HIVAT: CD4$\mathrm{Au}-\mathrm{Fe}_{3} \mathrm{O}_{4}$ ), the lanes 6-7 (HIVAT: $\mathrm{CD} 4-\mathrm{SiO}_{2} ;-\mathrm{Fe}_{3} \mathrm{O}_{4}$ ), the lane 2 (anti-gp120-Au-Fe3O4), the lane 3 (anti-gp120- $\mathrm{SiO}_{2}-\mathrm{Fe}_{3} \mathrm{O}_{4}$ ), and from the $\mathrm{HBV}+$ patient 1 loaded into the lane 8 , while all were labeled with anti-gp120 derivatized with SPM. This is a raw image acquired in white light illumination, with no post-acquisition manipulation. VAT guiding domains incorporating CD4 mutations and isotype anti-gp120 resulted in empty lanes. Middle pane. Three-dimensional quantification of the immunoblot in the left pane. Right pane. Top values quantification of the immunoblot in the left pane. 


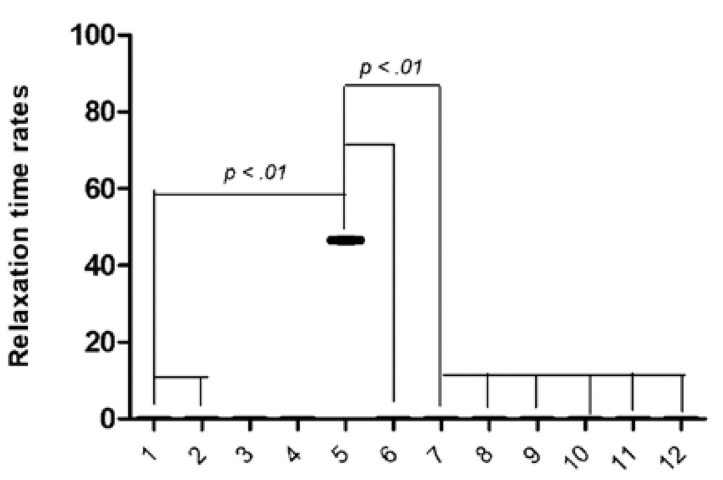

Apheretic fractions

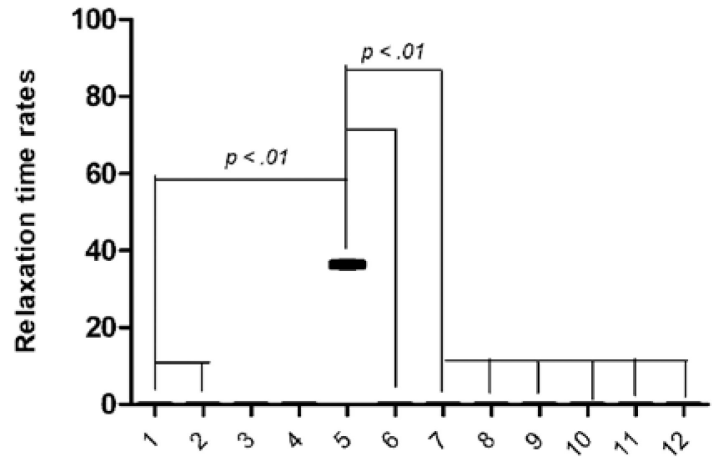

Apheretic fractions

FIG. 3.

Left pane. Quantified changes in relaxation time rates (y axis: relative units) measured in blood from the healthy donor 1 (x axis: Apheretic fractions) (1-4), HIV+ patient 1 (5-8), and HBV+ patient 1 (9-12) after administration of VAT followed by apheresis. All relaxation time readouts of the samples containing the VAT apheresed material (1, 3, 5, 7, 9, $11)$ are compared with the residual after apheresis (following even numbers). VAT: CD4-Au$\mathrm{Fe}_{3} \mathrm{O}_{4}(1-2,5-6,9-10)$, mut CD4- $\mathrm{Au}-\mathrm{Fe}_{3} \mathrm{O}_{4}(3-4,7-8,11-12)$ adjusted to equal molarity. All samples were measured in triplicates for each VAT and for each patient. The data are representative for all measurements performed. Right pane. Quantified changes in relaxivity measured in lymph from the healthy donor 3 (1-4), HIV+ patient 3 (5-8), and HBV+ patient 3 (9-12) after administration of VAT followed by apheresis. All labels the same as in left pane. All samples were measured in triplicates for each VAT and for each patient. The data are representative for all measurements performed. 


\section{HIVAT aided reduction of HIV viremia in blood of HIV+ patients}

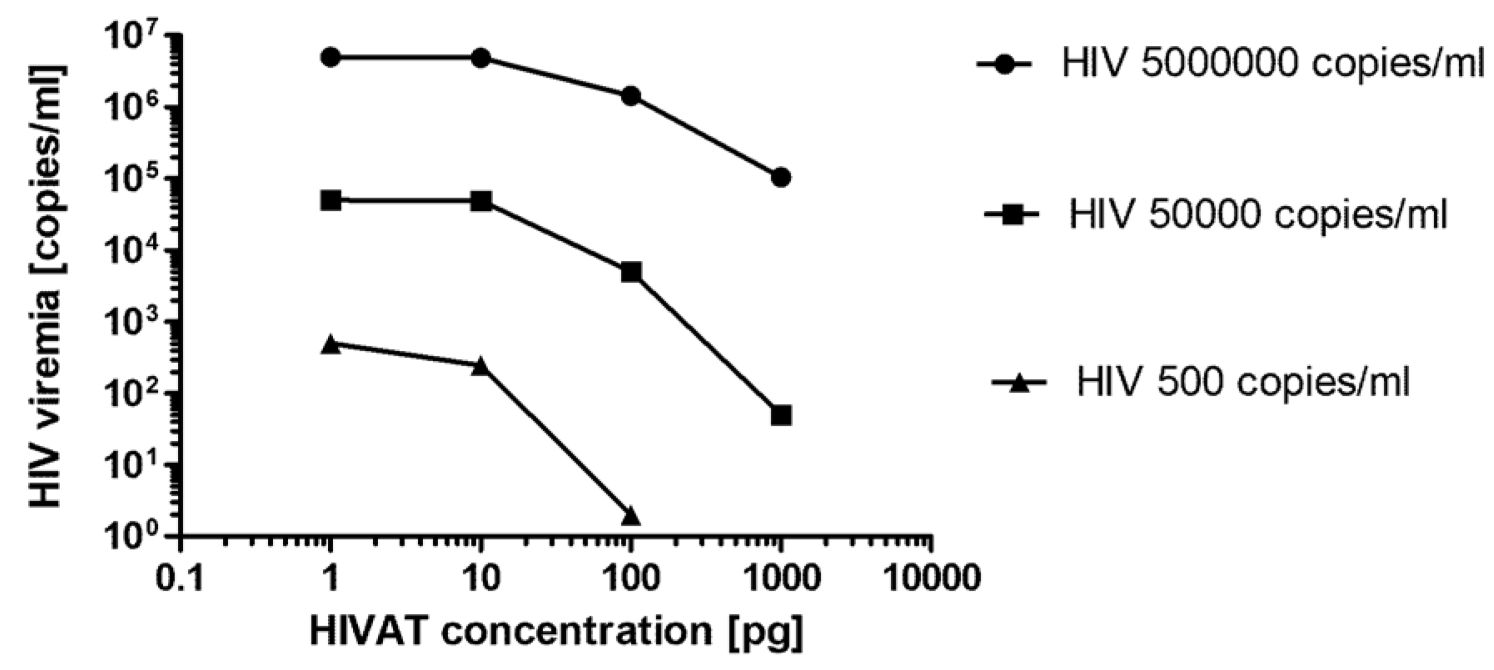

FIG. 4.

Rapid reduction of the various heights of HIV viremia in blood of the HIV+ patients was attained by means of VAT aka genomically engineered molecules with superparamagnetic domains aided apheresis. The HIV copy numbers were determined in blood by polymerase chain reaction with the HIV specific primers. 


\section{HIVAT aided represion of HIV viremia in blood of HIV+ patients over time}

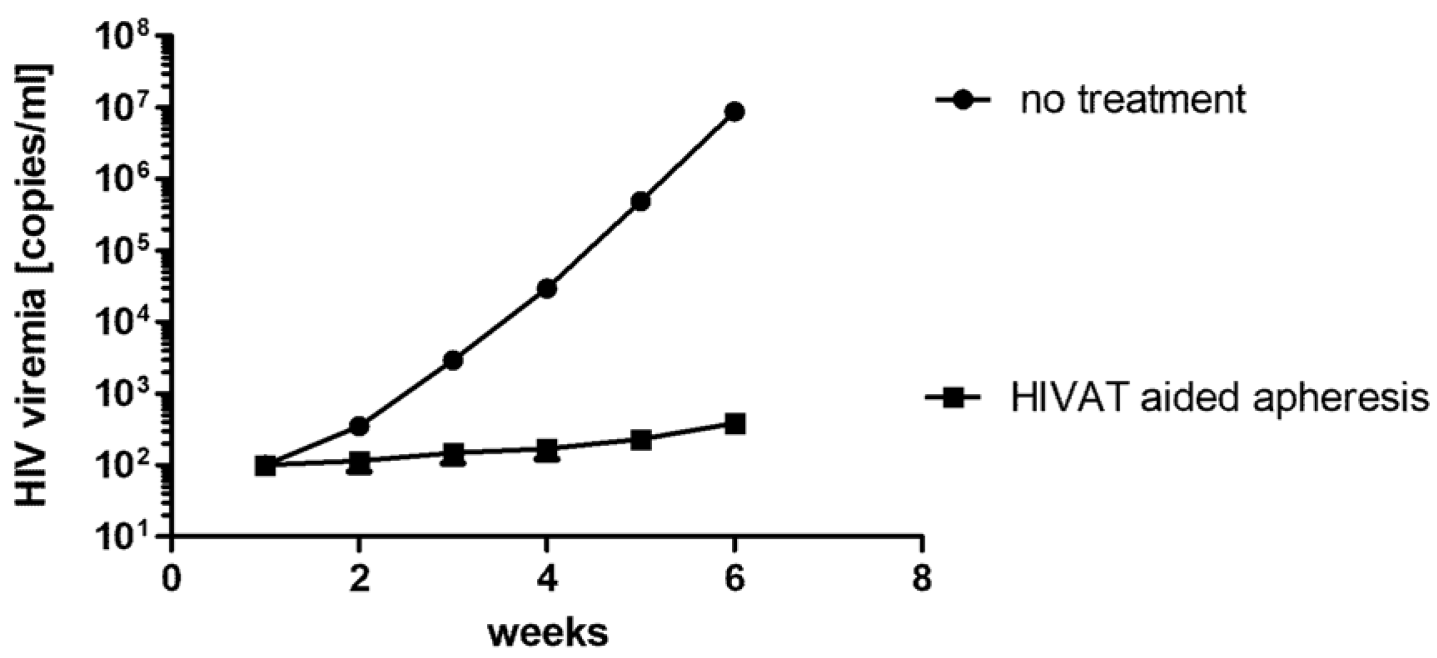

FIG. 5.

HIV viremia in blood of the HIV+ patients was repressed over time by administering HIVAT aka HIV targeting genomically engineered molecules featuring superparamagnetic properties (GEM-SPM). The HIV copy number was determined in blood by polymerase chain reaction with the HIV specific primers. 


\section{HIVAT aided prevention against HIV viremia in blood of HIV+ patients}

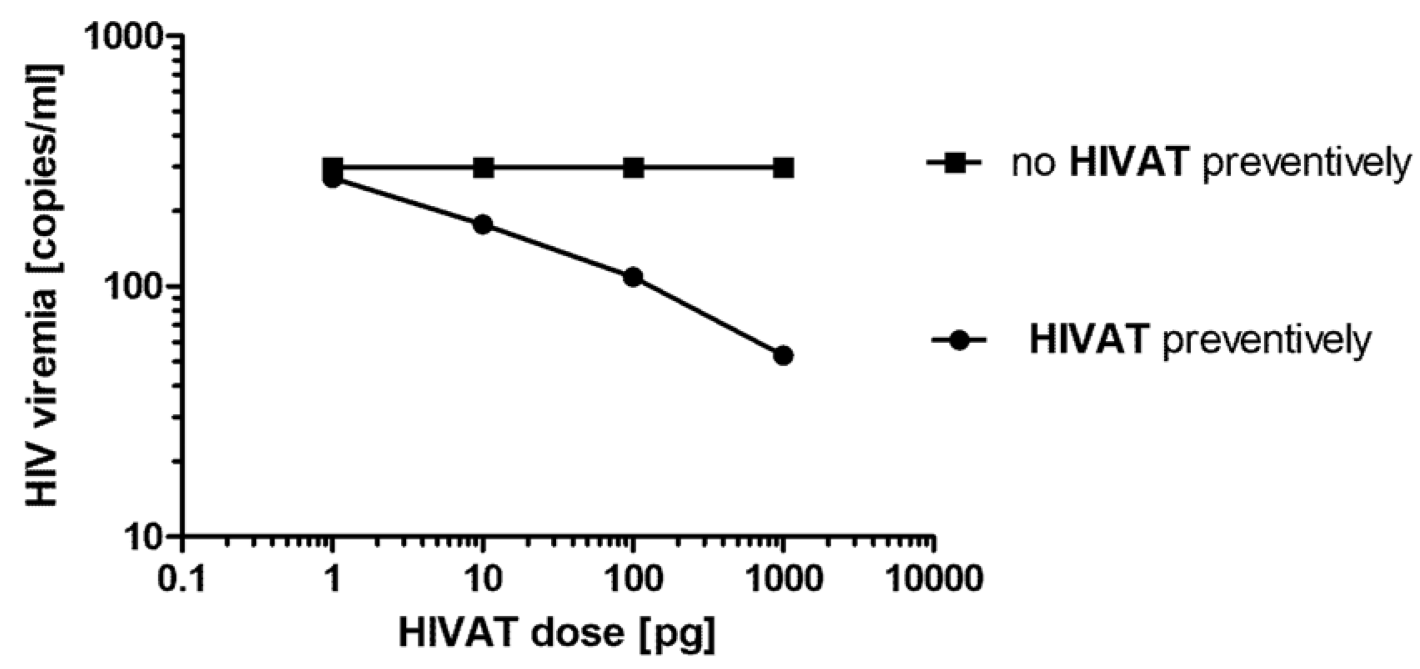

FIG. 6.

Prophylactic administration of VAT aka HIVAT prior to the HIV infection resulted in significant reduction of the HIV viremia upon infection. The HIV copy number was determined in blood by q-RT-PCR with the HIV specific primers. 
HIVAT aided reduction in HIV new infections of CD4+ lymphocytes

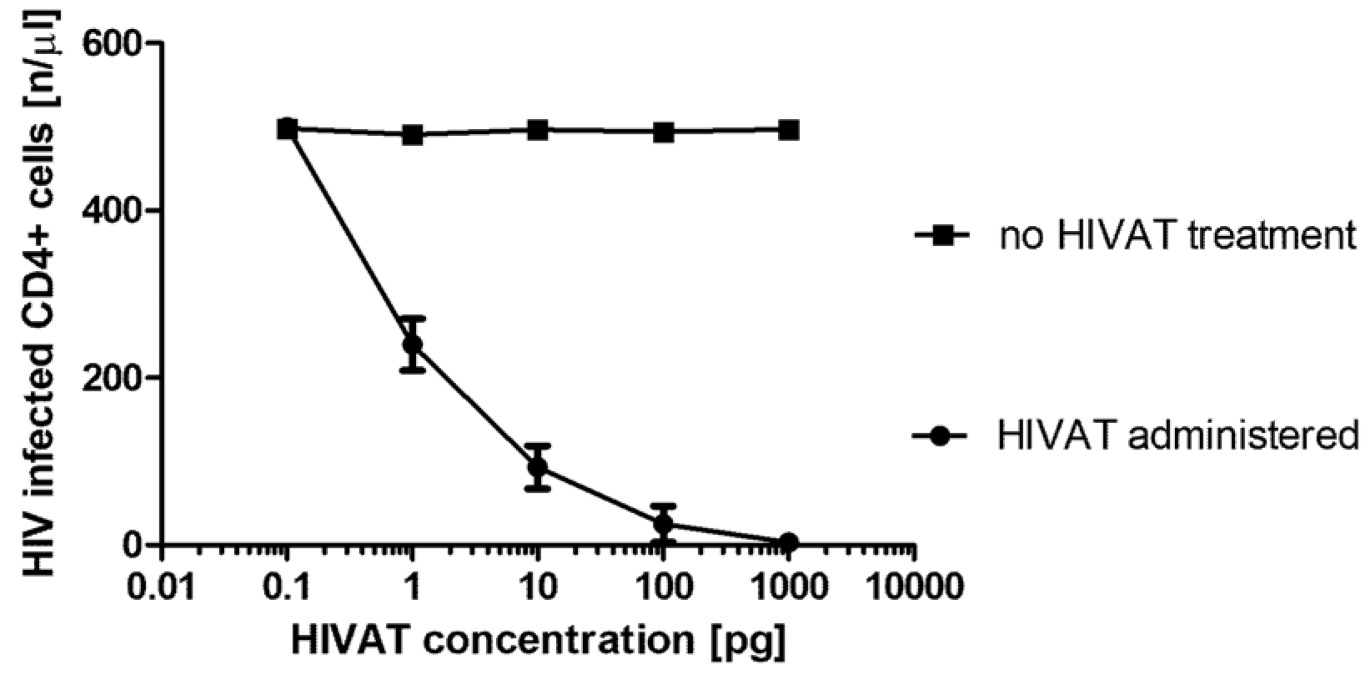

FIG. 7.

Significantly reduced number of CD4+ lymphocytes, which became newly infected with HIV, if infection occurred after administration of HIVAT aka genomically engineered molecules featuring superparamagnetic properties (GEM-SPM). The CD4+ lymphocyte count was conducted by flow cytometry after labeling with anti-CD4 antibodies rendered fluorescent with phycoerythrin. 


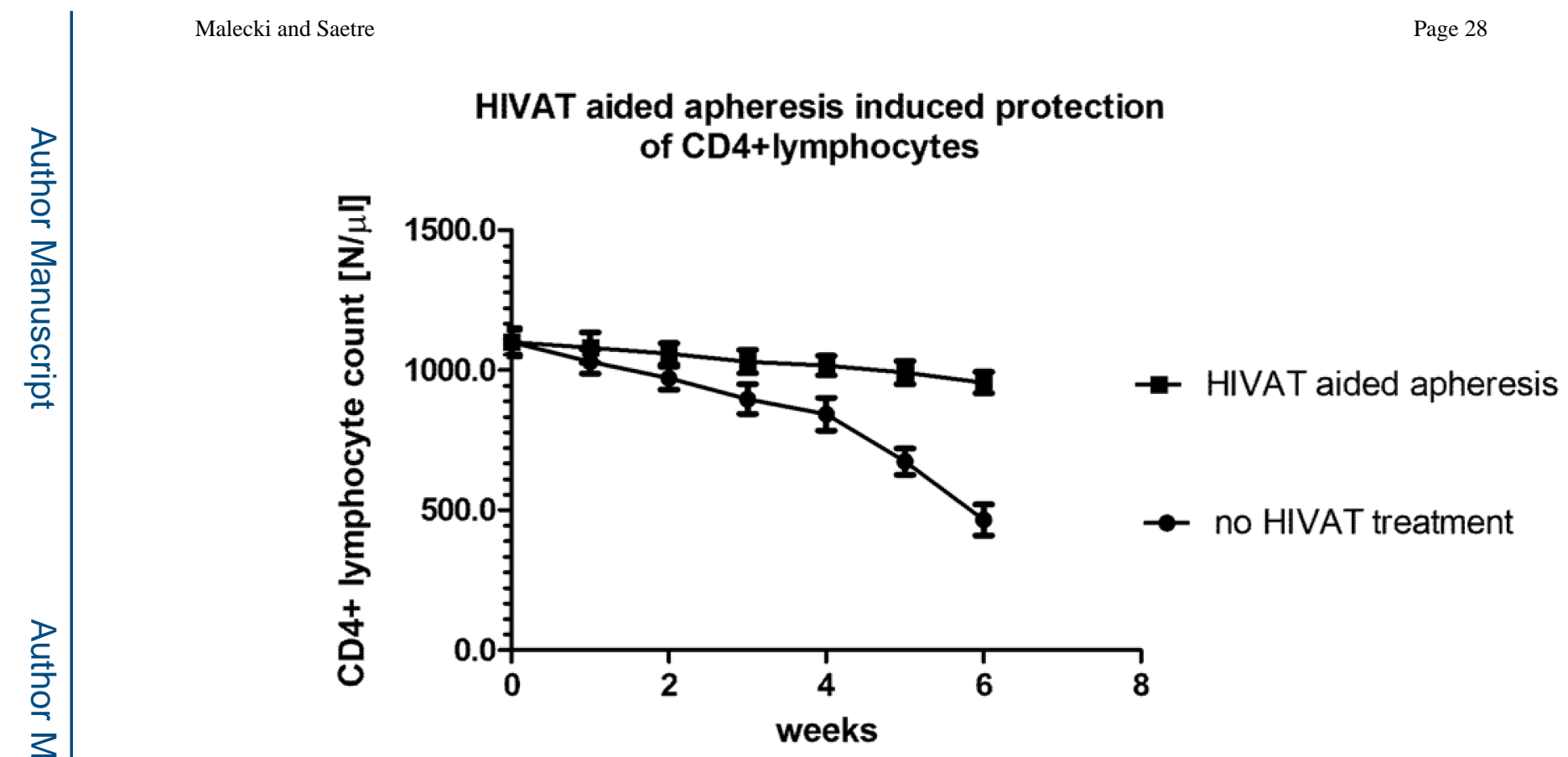

FIG. 8.

CD4+ lymphocyte population is protected by administration of HIVAT aka VAT, which is repressing the viral count, therefore is reducing CD4+ lymphocyte cytopathic depletion. The CD4+ lymphocyte count was conducted by flow cytometry after labeling with anti-CD4 antibodies rendered fluorescent with phycoerythrin. 